\title{
Enterohaemorrhagic Escherichia coli O104:H4: are we prepared now?
}

A W Friedrich (alex.friedrich@umcg.nl)1

1. Department of Medical Microbiology and Infection Control, University Medical Centre Groningen, University of Groningen, the Netherlands

Citation style for this article:

Friedrich AW. Enterohaemorrhagic Escherichia coli $0_{104}: \mathrm{H}_{4}$ : are we prepared now?

Euro Surveill. 2011;16(31):pii=19938. Available online: http://www.eurosurveillance.org/ViewArticle.aspx?Articleld=19938

Article published on 4 August 2011

It is over. The outbreak of the enterohaemorrhagic Escherichia coli (EHEC) $0104: \mathrm{H}_{4}$ infection that had its major focus in Germany [1] and affected people in many other European countries has officially come to an end [2]. While the media coverage has been decreasing, the scientific community has been working to understand the reason why this dramatic outbreak occurred. We have learnt that the pathogen is not a totally new clone, but is a slight variant of a known - although rarely described - EHEC, called HUSEC-41 [3] with an extended-spectrum beta-lactamase (ESBL) resistance. Furthermore, the strain carries genes typically found in two types of pathogenic $E$. coli, the enteroaggregative E. coli (EAEC) and EHEC $[4,5]$. It specifically carries the genes for the classical haemolytic uraemic syndrome (HUS)-associated Shiga toxin 2.

Despite the efforts that have been made, major questions currently remain unanswered, such as why women were affected more than men, why the attack rate was so high, what the primary source was and what the reservoir is, how long people are carriers, what the importance of the ESBL resistance is, what the infectious dose is for this outbreak strain and what the role of secondary transmission is via symptomatic or asymptomatic carriers, directly to other persons or indirectly via an index source, such as food.

It is known that up to $15 \%$ of EHEC cases can be a result of secondary transmission arising from household contact with people who have sporadic EHEC infections [6]. In this issue of Eurosurveillance, two articles, Aldabe et al. [7] and Hauri et al. [8] report on secondary transmission during the EHEC $\mathrm{O}_{104}: \mathrm{H}_{4}$ outbreak. The first reports on a symptomatic man who transmitted EHEC to his wife and young daughter during the EHEC 0104: $\mathrm{H}_{4}$ infection in France [7]. Interestingly, the EHEC that was isolated from the mother apparently lost its ESBL resistance, confirming the known mobility of plasmids carrying resistance genes. This fact should be taken into consideration in diagnostic laboratories if $\mathrm{ESBL}$ resistance of EHEC $\mathrm{O}_{104}: \mathrm{H}_{4}$ is used for primary selection of the pathogen from stools without using also non-selective enrichment and detection of Shiga toxin genes.

The second article [8] illustrates in detail the history of six possible household transmissions, two possible nosocomial and one possible laboratory transmission in the German State of Hesse, where satellite clusters occurred. These cases throw light on three crucial issues. First, secondary transmission of EHEC 0104: $\mathrm{H}_{4}$ was shown not to be more frequent than expected. Second, the importance of microbiological serotyping was highlighted, as EHEC of other HUS-associated serogoups (0157, 091, and 0103) were also identified during the outbreak. Serotyping data are rarely available, due to the need for time-consuming techniques usually only carried out in specialised reference labs. This shows the need for the development of rapid seroand pathotyping methods for all HUS-associated $E$. coli strains. Third, infection control in hospitalised patients with EHEC infection needs specific consideration, as does laboratory safety in the handling of EHEC. It is not without reason that in most countries of the European Union EHEC is classified as a biosafety level (BSL)-3** microorganism (but no high-efficiency particulate air (HEPA) filter is required).

Both articles illustrate the importance of personal hygiene in preventing secondary transmission. In general, EHEC does not behave differently to any other organism transmitted via the faecal-oral route, but our 'preventive doors' for such organisms seem to stay wide open. We have become used to the fact that hundreds of thousands of Europeans have diarrhoea every year and a certain lack of basic hygiene seems to be acceptable, as usually nothing very severe happens. We often lack time for hand hygiene as we consider it not to be of great importance. However, diarrhoea is not a normal state. We forget that most enteropathogens are less infectious than EHEC or do not lead to such severe disease with such social visibility. This brings us to the biggest challenge. Circulating highly pathogenic and/ or multiresistant microorganisms can be detected at a very early stage, before large outbreaks of disease occur. Preventive microbiology is a basis for preventive 
medical advice and decision-making to protect people from infections. In future, European-wide coordination of preventive microbiology will be crucial for early detection of major health threats caused by infectious diseases. Its success will depend on our international and interdisciplinary efforts to foster protection against infection.

This outbreak is over. Let us get prepared!

\section{References}

1. Frank C, Werber D, Cramer JP, Askar M, Faber M, an der Heiden $M$, et al. Epidemic profile of Shiga-toxin-producing Escherichia coli $0_{104}: \mathrm{H}_{4}$ Outbreak in Germany - preliminary report. N Engl J Med. 2011 Jun 22. [Epub ahead of print]

2. Robert Koch Institute (RKI). Informationen zum EHEC/HUSAusbruchsgeschehen - Ende des Ausbruchs [Information about the EHEC/HUS-outbreak- end of the outbreak ]. Berlin: RKI; 2011. German. Available from: http://www.rki.de/cln_117/ nn_467482/DE/Content/InfAZ/E/EHEC/Info-HUS,templateld=ra w, property=publicationFile.pdf/Info-HUS.pdf

3. Mellmann A, Bielaszewska M, Köck R, Friedrich AW, Fruth A, Middendorf $B$, et al. Analysis of collection of hemolytic uremic syndrome-associated enterohemorrhagic Escherichia coli. Emerg Infect Dis. 2008;14(8):1287-90.

4. Bielaszewska M, Mellmann A, Zhang W, Köck R, Fruth A, Bauwens A, et al. Characterisation of the Escherichia coli strain associated with an outbreak of haemolytic uraemic syndrome in Germany, 2011: a microbiological study. Lancet Infect Dis. 2011 Jun 22. [Epub ahead of print]

5. Mellmann A, Harmsen D, Cummings CA, Zentz EB, Leopold SR, Rico A, et al. Prospective genomic characterization of the German enterohemorrhagic Escherichia coli 0104:H4 outbreak by rapid next generation sequencing technology. PLoS One. 2011;6(7):e22751.

6. Parry SM, Salmon RL. Sporadic STEC 0157 infection: secondary household transmission in Wales. Emerg Infect Dis. 1998;4:657-61.

7. Aldabe B, Delmas Y, Gault G, Vendrely B, Llanas B, Charron M, et al. Household transmission of haemolytic uraemic syndrome associated with Escherichia coli $0_{104}: \mathrm{H}_{4}$, south-western France, June 2011. Euro Surveill. 2011;16(31):pii=19934. Available from: http://www.eurosurveillance.org/ViewArticle. aspx?Articleld=19934

8. Hauri AM, Götsch U, Strotmann I, Krahn J, Bettge-Weller G, Westbrock HJ, et al. Secondary transmissions during the outbreak of Shiga toxin-producing Escherichia coli O104 in Hesse, Germany, 2011. Euro Surveill. 2011;16(31):pii=19937. Available from: http://www.eurosurveillance.org/ViewArticle. aspx?Articleld=19937 